\title{
FIRE PREVENTION IN NOVA SCOTIA ${ }^{1}$
}

\author{
By G. W. I. CREIGHTON
}

Deputy Minister, Department of Lands and Forests, Nova Scotia

$\mathrm{T}$

HE Province of Nova Scotia with a forest area of about ten million acres rankes fifth among the provinces of Canada as a producer of forest wealth and fourth as a producer of sawn lumber. Its forests supply the raw material for one paper mill, three pulp mills and over seven hundred sawmills and woodworking plants, and in 1947 the value of all forest products was estimated to be in excess of forty-three million dollars.

The problem of preventing fires in the forest is apparently as old as the province itself, and some areas had been burned before permanent settlements were establishd.

In 1761, just twelve years after the founding of Halifax, the Provincial Legislature passed an Act "To prevent damages by unseasonable burning or firing of the woods". The preamble to this Act describes how settlers' fires set in dry periods had caused serious damage in the new settlements and the Grand Jury was empowered to set up regulations for burning and to impose fines for infractions of the regulations.

From that time on additional legislation has been passed from year to year with the object of eliminating fire losses, but no direct action was taken until 1904, in which year Chief Rangers were appointed for each municipality in the province.

The rangers received their appointment from the Provincial Government, but all costs were paid by the municipalities. Each ranger was required to make an annual report to the Commissioner of Crown Lands setting forth work carried out during the year, area burned, estimated damage and fire fighting costs.

These figures were first compiled and published in 1915, in which year thirty-nine fires burned an area of thirteen thousand three hundred and thirteen acres.

Fire protection in Nova Scotia remained the responsibility of the municipalities until 1927, when full responsibility for protecting all woodlands in the province was assumed by the Department of Lands and Forests, which had been organized in 1926 by merging the Department of Crown Lands with the Department of Forests and Game.

In the period from 1927 to 1948 very considerable progress has been made and the Department of Lands and Forests now owns two hundred and forty-one motor pumps, more than six hundred thousand feet of motor hose, over four thousand hand pumps and six bulldozers, together with a fleet of trucks, jeeps and a large supply of other miscellaneous equipment.

The Department also maintains thirteen fire towers, and operates an aerial patrol which in 1947 Alew in excess of thirteen hundred hours.

During the past summer a new repair shop and storage depot was completed to service fire fighting equipment, and in 1949 a much better repair service than ever before will be provided.

1. Paper presented at the fortieth annual meeting of the Canadian Society of Forest Engineers, Fredericton, N.B., October 4 to 7,1948 . 
At the present time Nova Scotia is broken up into six districts under District Foresters, and present plans call for an increase to ten districts. The large districts in turn are broken down into seventy-seven ranger districts in charge of fire rangers.

For many years settlers' fires, railway fires, and fires set by portable steam mills caused the greatest damage but restrictive legislation has been passed and enforced which has reduced fire losses from these three causes to a very marked degree.

A study of the records for the ten year period from 1938 to 1947 shows that during that time a total of two thousand seven hundred and thirty-five fires burned an area of one hundred and sixty thousand seven hundred and seventy-one acres causing an estimated property loss of $\$ 938$,375.75 and costing $\$ 319,665.56$ for actual fire fighting, exclusive of fixed expenditures for permanent staff, capital cost of and maintenance of equipment.

During that period the known causes of fire in their order of importance were:

\begin{tabular}{|c|c|c|}
\hline Careless Smokers & & \\
\hline $\begin{array}{l}\text { Careless Smokers } \\
\text { Campers }\end{array}$ & $\begin{array}{l}697 \\
312\end{array}$ & "ires \\
\hline Incendiary & 293 & “ \\
\hline Fishermen & 271 & " \\
\hline Berry Pickers & 247 & " \\
\hline Children playing with fire & 212 & " \\
\hline Brush Burning & 170 & $"$ \\
\hline Railways & 146 & " \\
\hline Burning Buildings & 112 & " \\
\hline Sawmill and Industrial & 72 & $"$ \\
\hline Lightning & 19 & $"$ \\
\hline Fires of undetermined origin & 184 & \\
\hline Total & 2,735 & Fires \\
\hline
\end{tabular}

The yearly fire fighting costs and estimated losses were as follows:

$\begin{array}{lrr} & \text { Costs } & \text { Property Loss } \\ 1938 & \$ 5,037.95 & \$ 2,869.00 \\ 1939 & 22,834.83 & 6,997.25 \\ 1940 & 16,164.85 & 4,532.00 \\ 1941 & 4,708.29 & 2,500.00 \\ 1942 & 23,399.88 & 99,744.50 \\ 1943 & 2,289.36 & 1,238.00 \\ 1944 & 44,019.66 & 106,518.00 \\ 1945 & 9,475.83 & 11,372.00 \\ 1946 & 48,093.89 & 41,135.00 \\ 1947 & 143,641.02 & 661,470.00 \\ & \$ 319,665.56 & \$ 938,375.75\end{array}$


While figures for 1948 are not yet complete indications are that fire losses may be the smallest since records have been kept.

Many of the problems and conditions met in Nova Scotia are common to all forest regions, but others are possibly peculiar to Nova Scotia.

Due to its shape and geographical location no part of Nova Scotia is farther than thirty miles from tidewater, and the resultant maritime climate is favourable from the point of view of fire protection.

Most of the province is traversed by public highways, and the transportation of men and equipment is not the problem that it is in more remote regions. On the other hand these same highways provide the general public with easy access to the forests, and our fires are most frequent near the roads and near centres of population.

Among fires classed as incendiary are fires set to burn for blueberries, fires set to make feed for moose and deer and with the mistaken idea that wood ashes will rid moose of ticks, and fires which are set in one county only to provide hardwood suckers suitable for hoop poles.

In surveying the whole problem of forest fires in Nova Scotia, it appears that measures of prevention have not kept pace with detection and suppression.

During the early 1920's a lecture tour was started by the Canadian Forestry Association, cooperating with the Department of Forests and Game. Since then, fire prevention campaigns have been somewhat spasmodic, but have been gathering momentum in the last few years.

In 1938 a sum of $\$ 562.90$ was spent by the Department of Lands and Forests for all advertising purposes, including fire prevention. By 1947 this had grown to $\$ 5,920.04$, and in 1948 it will approach twenty thousand dollars.

As elsewhere, use is made of the press, the radio, motion pictures, wall posters, leaflets, etc., and valuable assistance is received from the Department of Education, the Canadian Forestry Association, Fish and Game Clubs and other organizations.

For several years an Extension Forester has been employed whose duties include educational work in the schools.

For several years the Department of Lands and Forests in cooperation with the Department of Education has promoted the Green Forest League in the schools of the province.

Approximately one hundred thousand school children were enrolled and took a pledge to help protect the forests of the province. After taking the pledge, each pupil was given a Certificate of Membership and a lapel button, together with wall posters and literature.

Last year a number of Boy Scouts were appointed Junior Forest Wardens, and several forestry courses were given to scouts at a number of places in the province.

Tree planting by school children has been carried on for a number of years in an attempt to win their interest and support. 
One proof that interest may be encouraged in this way is the fact that several of Nova Scotia's District Foresters first became interested in forestry through the tree planting which they did while members of scout troops.

While more propaganda and education is needed to gain public support, fires cannot be completely eliminated, or even successfully controlled, while bad fire hazards exist and fire hazards are present in abundance.

Of all existing hazards, logging slash is probably the greatest. At the present time it is neither possible nor desirable to remove all logging slash, but fire losses would be materially reduced if slash were removed from the boundaries of public roads and along lake shores.

During the past three years, stand-by crews of fire fighters have been employed in Nova Scotia. While not engaged on fires these men have been employed building roads on Crown Lands. It would seem wise to employ at least some of these men in cleaning up slash where the greatest hazard exists, and additional legislation is needed which will regulate cutting and prohibit lumber operators and others from leaving brush along the roads, on lake and stream boundaries, or in the boundary lines of separate properties.

Such legislation will be quite in line with the Small Tree Conservation Act, and would merely be another step towards better forest management.

In the final analysis it would seem that the greatest possibility of preventing fires lies in better management which will lessen the danger from fire, for no matter how efficient our fire fighting system may be or how fire conscious the general public may be, if we fail to make our forests proof against fire, every so often we will be faced with a set of conditions favourable for the rapid spread of fire, and severe losses will be suffered. 